\title{
PENALIDE E COLÔNIA: \\ a responsabilização criminal dos escravos na Capitania de Pernambuco durante o período colonial
}

Lincoln Régis de Oliveira Júnior*

RESUMO: Durante o período colonial, vários negros oriundos da África desembarcaram no Brasil, principalmente na Colônia de Pernambuco, para servirem como mão-de-obra escrava para uma economia açucareira submetida ao governo português. Assim, em uma perspectiva jurídica, surge a necessidade de compreender qual era o verdadeiro tratamento que os escravos tinham perante o sistema jurídico-criminal que vigeu no Brasil colonial, especialmente em Pernambuco. Este estudo só se tornou possível após a coleta de amplo material bibliográfico e por meio da adoção de uma análise exegética das normas vigentes e dos processos criminais da época, além de consultas à órgãos nacionais e internacionais.

Palavras-chaves: Direito Penal. Penalidade. Escravidão. Período colonial. Capitania de Pernambuco

\section{PENALTY AND COLONY: the criminal responsibility of the slaves at the Capitania de Pernambuco during the colonial period}

\begin{abstract}
During the colonial period, several negroes from Africa landed in Brazil, mainly in the Colony of Pernambuco, to serve as slave labor for a sugar economy submitted to the Portuguese government. Thus, from a juridical perspective, arises the need to understand the true treatment that the slaves had towards the criminal-legal system that was in force in colonial Brazil, especially in Pernambuco. This study was only possible after the collection of extensive bibliographical material and through the adoption of an exegetical analysis of the norms and criminal processes of that time, in addition to consultations with national and international entities.
\end{abstract}

Keywords: Criminal Law. Punishment. Slavery. Colonial period. Capitania de Pernambuco.

\footnotetext{
* Mestrando em Direito Penal - História das Ideias Penais pela Faculdade Damas da Instrução Cristã FADIC; Bacharel em Direito pela Universidade Católica de Pernambuco - UNICAP e Advogado. E-mail: lincolnjunior@outlook.com. Recife-PE.
} 


\section{INTRODUÇÃO}

O início do processo de colonização de fato do Brasil realizado pelos portugueses abriu a rota para os milhares de navios negreiros e, por consequência, à grande quantidade de escravos negros oriundos da África que desembarcaram em solo brasileiro, sobretudo na Capitania de Pernambuco, para servirem como mão-de-obra, funcionando como instrumentos de produção para os seus senhores. Este processo de escravização tinha como principal característica a eliminação dos direitos mais inerentes à dignidade da pessoa humana, sobretudo em razão da instrumentalização deles.

Desta maneira, verificado que nas mãos dos senhores de engenhos os negros africanos se tornavam coisas, sendo considerados como propriedades daqueles, sem qualquer direito cível, surge como imprescindível compreender acerca do tratamento jurídico que era dispensado aos escravos na seara criminal durante o período da Colônia. Ou seja, demonstra-se como sendo de suma importância analisar se eles eram res ou homens perante o direito criminal vigente na época. Esta análise só se tornou viável após a coleta das normas penais vigentes que colaborasse para uma análise do sistema punitivo que vigia na época do Brasil colonial, principalmente em Pernambuco.

Após a leitura de textos que tratam do Brasil Colônia sob uma perspectiva jurídica e a partir de uma análise exegética do corpo normativo vigente na época, sobretudo da Carta de Doação da Capitania de Pernambuco, das Ordenações do Reino que maior aplicação teve no Brasil e das demais normas extravagantes que foram coletadas, bem como a partir da observação das espécies de castigos aplicados aos escravos, que só foi possível após uma vasta pesquisa bibliográfica e documental, explicar-se-á não apenas a existência de uma justiça privada e de uma justiça oficial, mas corroborará a compreender como os escravos eram submetidos a estes dois tipos de justiças que coexistiam, buscando entender a relação das penas e/ou castigos que eram cominadas aos escravos em razão das sanções que eram destinadas aos demais membros do corpo social.

Ou seja, estudar-se-á as legislações penais emitidas pela Coroa portuguesa ao Brasil que tinham como objetos o adestramento e docilização dos escravos, buscando compreender a forma como os escravos eram vistos diante da lei. Entretanto, não se pode olvidar de analisar o período da ocupação holandesa na Capitania de Pernambuco e da aplicação, ainda que não 
tão duradoura, de seu direito penal, além da realização de um estudo do direito aplicado dentro do maior símbolo de resistência dos escravos, o Quilombo.

Após a aquisição de um conhecimento mais aprofundado acerca do direito penal durante o Brasil Colônia, mormente acerca da aplicação da legislação criminal na Capitania de Pernambuco para escravos, realizar-se-á, para uma melhor compreensão de como os escravos eram tratados diante do Direito Penal, além do plano abstrato, uma análise dos processos jurídicos-criminais em que escravos figuraram como parte, análise esta que só foi possibilitada após a realização de um mapeamento e consulta a organismos nacionais e internacionais, com o fito de obter maiores documentos que pudessem corroborar com esta análise processual.

\section{O NOVO MUNDO: A COLONIZAÇÃO DA AMÉRICA PORTUGUESA}

Apenas depois de 30 anos desde a chegada dos primeiros portugueses no Brasil, que ocorreu em 1500, é que Portugal começa a prestar atenção em sua colônia na América. O principal motivo para este desinteresse na formação de um núcleo colonizador nestas terras durante as três primeiras décadas do século XVI, deu-se, sobretudo, porque a forma precária de ocupação, realizada por meio da construção de feitorias no litoral brasileiro, satisfazia aos interesses da Coroa lusitana e dos comerciantes portugueses, que estavam mais preocupados com a obtenção de especiarias (DORIA, 2012, p. 13-14), em especial porque estes produtos que vinham do oriente era que produziam um maior lucro à Metrópole, sendo, portanto, as especiarias, um produto mais rentável ao governo português.

Embora o mercado de especiarias fosse a mais importante fonte de renda do governo lusitano, a nova colônia portuguesa na América também contribuiu, ainda que de forma incipiente, para a economia portuguesa. Isto porque, em primeiro momento, para os portugueses, os principais produtos que o Brasil poderia oferecer com o fito de favorecer a economia portuguesa seria, entre outros produtos, o pau-brasil e a pimenta que eram colhidos pelos índios e entregues aos portugueses, que chegavam em expedições para a defesa, reconhecimento das terras e extração de riquezas.

Durante os primeiros anos de 1500, as atividades portuguesas no Brasil ficaram adstritas à região beira-mar brasileira. Entretanto, após ameaças ao domínio da América portuguesa e, em razão disto, do fundado receio de perder as terras brasileiras para a Espanha e França, a Coroa lusitana envia uma expedição colonizadora. Esta atividade ficou a cargo de 
Martim Afonso de Souza, que, em 1532, funda o primeiro núcleo colonizador no Brasil, com a Vila de São Vicente, dando início, desta forma, ao Período Colonial, com a colonização de fato das terras brasileiras.

Com o processo de colonização das terras brasileiras, deixa de viger o sistema de feitorias, que era adstrita apenas ao litoral do Brasil, e passa a ser implantado um novo sistema administrativo, o sistema de Capitanias Hereditárias. Destaque-se que esta novel forma de organização das terras brasílicas tinha como principal objetivo, assim como afirmam Karina Nogueira Vasconcelos e Rodrigo Teles de Oliveira (2016), a descentralização políticoadministrativa das colônias que, embora continuassem sendo um domínio português, eram administradas por fidalgos nomeados pelo monarca lusitano, a quem delegavam toda a jurisdição civil e criminal. Exemplo disto é a Capitania de Pernambuco, que foi concedida pelo Rei D. João III, por meio da Carta de Doação datada de 05 de setembro de 1534, ao nobre Duarte Coelho Pereira, que utilizou de suas terras para a produção de cana-de-açúcar.

Com a obtenção dos primeiros resultados positivos no cultivo da cana-de-açúcar no nordeste brasileiro, mais especificamente na Colônia de Pernambuco, em razão do clima e do tipo de solo, dois elementos que favoreceram demasiadamente esta atividade, verificou-se que a produção desta matéria-prima geraria grandes ganhos econômicos à Portugal, sobretudo pelo fato de que o açúcar produzido no Brasil era um produto de fácil aceitação no mercado europeu, o que acabaria por compensar os esforços até então despendidos para a colonização.

Embora, em princípio, o processo de colonização da América portuguesa tenha sido estimulada pela Metrópole para a proteção de seu domínio no além-mar, passando a incentivar o processo de ocupação na América portuguesa e a autossuficiência das Capitanias Hereditárias, com a colonização realizada diretamente pelos donatários, por meio da concessão das Cartas de Doação, o que livraria a Coroa portuguesa de aportes econômicos, já que eram aqueles quem iriam suportar os gastos com o processo de colonização (VASCONCELOS; OLIVEIRA, 2016), animada com os resultados obtidos com a produção açucareira, o maior estímulo à colonização só ocorrera posteriormente com o processo de centralização administrativa, com o estabelecimento do sistema de Governos-Gerais, sobretudo porque a produção do açúcar resultou em grande retorno econômico para a Coroa lusitana, que, a partir disto, passou a se concentrar, sobretudo, na produção do açúcar em terras brasílicas. Saliente-se, entretanto que, das capitanias brasileiras, apenas a de Pernambuco apresentou grande desenvolvimento econômico nos primeiros períodos da colonização. 
Entretanto, para o regular funcionamento de um engenho de cana-de-açúcar, era necessária uma grande quantidade de mão-de-obra.

A utilização da mão-de-obra escrava, desta maneira, aparece como única solução possível, uma vez que não era viável trazer trabalhadores assalariados oriundos de Portugal ou de qualquer outro país europeu, pois, como assevera Wolkmer (1998, p. 51): “estes poderiam tornar-se donos de um pedaço das terras devolutas que existiam em abundância”. Ou seja, em razão da existência de uma grande extensão territorial ainda não ocupada, a chegada de trabalhadores assalariados em terras brasílicas poderia gerar, ao invés de mão-de-obra, concorrência para os senhores de engenho, tornando os imigrantes assalariados em verdadeiros colonos.

Desta forma, observada a impossibilidade de utilizar a mão-de-obra assalariada estrangeira e evidenciada a necessidade de um quantitativo enorme de mão-de-obra para trabalhar nos engenhos, os colonos tentaram submeter, em um primeiro momento, ao trabalho forçado, os índios que eram capturados na região ou que eram comprados dos bandeirantes. Entretanto, tendo em vista que os nativos não conseguiram se adaptar bem ao trabalho, pois produziam pouco e, em geral, morriam logo depois de aprisionados, viu-se como alternativa para esta situação a importação de uma mão-de-obra escrava oriunda de outro continente, para servirem como mão-de-obra dos engenhos existentes no Brasil. Saliente-se que estes escravos eram, sobretudo, advindos de colônias portuguesas na África, fazendo com que, na América Portuguesa, naquele período, negros e escravos fossem considerados sinônimos.

\section{O ESCRAVO COMO RES E HOMEM}

Com a chegada dos primeiros carregamentos de escravos oriundos da África, os senhores de engenho passaram a visitar Pernambuco, sobremaneira porque o porto de Recife além de ser o porto de saída do açúcar com destinação para o mercado europeu, era um dos portos que recebia o maior número de escravos oriundos dos domínios portugueses na África. Os africanos que chegavam em Recife eram expostos à venda no mercado de escravos e, consequentemente, vendidos como animais que poderiam ser domesticados, ou melhor, eram tratados como objetos, produtos comerciais, que eram adquiridos, vendidos, arrendados e herdados.

Entende-se, portanto, que o escravo era tido, antes de qualquer coisa, como uma propriedade privada de outro indivíduo, que trabalhava sobre coação física. O produto oriundo 
do trabalho do escravo não pertencia a este, pelo contrário, o fruto de seu labor pertencia exclusivamente ao seu senhor, ao seu proprietário. Tem-se, portanto, que a escravidão gera a instrumentalização de determinado indivíduo, sobretudo porque reduz um homem a instrumento/objeto de outro. O processo de escravidão do indivíduo influencia diretamente no exercício e fruição de seus direitos, isto porque este processo concede ao seu senhor, o seu dono, o poder de dispor sobre os direitos naturais dos seres instrumentalizados.

Destaque-se que a utilização de mão-de-obra escrava era fomentada inclusive pela Igreja Católica, religião influente e predominante na Europa, além de ser a religião oficial de Portugal e, por conseguinte, de suas colônias. Esta defesa em prol da escravização dos africanos, realizada pela igreja, tinha como principal argumento a justificativa de que Deus teria criado os africanos já com sua função dentro de um corpo social definida, sendo a escravidão para este povo uma realidade pré-concebida. Demais disto, a escravidão, além de ser algo destinado ao negro, tratar-se-ia de um castigo dado por Deus aos africanos por possuírem comportamentos ímpios e práticas religiosas consideradas diabólicas.

Nessa perspectiva, é importante compreender que os escravos eram realmente tratados como mercadorias, seres instrumentalizados cujo seus direitos estavam concentrados nas mãos de seus senhores, seus donos, que poderiam realizar o que bem quisessem, podendo inclusive dispor da vida deles, o que acabava por tornar os escravos em seres despidos de quaisquer direitos. Os escravos, portanto, não possuíam a prerrogativa para o exercício e fruição dos direitos mais inerentes à dignidade da pessoa humana, pelo simples fato de que, civilmente, não eram considerados como homens, mas apenas objetos, res.

A virada no tratamento jurídico do escravo só aparece quando este cometia algum delito. Enquanto que, civilmente, era tido apenas como ser despido de qualquer direito, no momento em que praticava algum crime, tornava-se homem penalmente responsável por seus atos, sobretudo porque a justiça não poderia julgar uma “coisa”, e, em razão disto, neste momento, tornava-se necessária a conversão da “coisa” em homem para que possa ser realizada a indispensável reponsabilidade penal. Ou seja, em outras palavras, pode-se asseverar que, embora os escravos fossem considerados res para os atos da vida cível, isto é, incapazes de adquirir e possuir direitos, eram considerados homens plenamente responsáveis para os atos praticados no âmbito criminal, tanto que, Jacob Gorender (1985, p. 51), ao constatar esta realidade no Brasil Colonial, acaba afirmando que "o primeiro ato humano de um escravo é o 
crime", pois, só neste momento em que o escravo poderia ser considerado homem, no demais, era visto como coisa, instrumento de seus senhores.

\section{ENTRE O CRIME E O CASTIGO}

Durante o período colonial brasileiro, além de servir como meio para otimizar a produção econômica, centrada no plantio da cana-de-açúcar, e diminuir a força política escravista, com o intuito de evitar o surgimento de rebeliões que atentassem à estabilidade do sistema de mão-de-obra imposto, qual seja, o sistema escravocrata, os castigos que eram aplicados aos escravos serviam, igualmente, como meio repressivo e preventivo para a prática de um crime. Nesse sentido, é pertinente compreender que existiam duas justiças paralelas: (i) a privada e; (ii) a oficial.

A justiça privada consistia no processo punitivo que era exercido pelos proprietários dos escravos, sem qualquer intervenção do poder estatal, ocorria dentro dos limites dos engenhos, em uma relação entre o dono e sua res. Este poder punitivo que era privativo dos senhores donos de escravos era considerado não apenas um direito que poderia ser facultado ao senhor de engenho, pelo contrário, era tido, antes de qualquer coisa, como um dever, uma obrigação que se impunha a este para que a ordem fosse mantida.

Saliente-se que, no âmbito da justiça privada, caberia apenas ao proprietário do escravo os critérios de avaliação e de aplicação dos castigos. Entretanto, ponto importante é ter em consideração que a execução dessa justiça, não raramente, ultrapassava o critério da justiça e da moderação, sobremaneira porque não havia um limite no poder de castigar dos senhores. Na aplicação dos castigos, neste tipo de justiça que vigia na época, não existia a questão da proporcionalidade. Esta desproporcionalidade evidente na aplicação dos castigos era, por um lado, legitimada pelo poder público, que não interferia no modo de punir e, por outro modo, era corroborada pela imaginação fértil da pessoa que tinha o escravo em seu domínio, em especial porque criava novos métodos e instrumentos de castigos, ou melhor, de torturas. Esse modo de castigar tão severamente os escravos, mesmo que não tivesse como principal objetivo a sua destruição, deixava-os, quando sobreviviam, deformados.

Este poder de punir do senhor de engenho não estava presente apenas quando o seu escravo cometia algum delito ou não realizava as atividades a ele designada, mas ocorria, igualmente, a mero bel-prazer de seu proprietário. E, se os castigos praticados pelos senhores de engenhos eram cruéis, pior é quando esses castigos eram praticados pelas esposas destes, as 
sinhás, nas escravas. Visto que as escravas, por viverem servindo suas sinhás, tinham uma vida mais ativa e, em consequência, acabavam por desenvolver corpos mais esbeltos, fato este que chamava a atenção dos senhores e, por causa disto, gerava uma raiva nas sinhás que se utilizavam dos castigos como forma de aliviar seus ciúmes. Neste mesmo sentido se posiciona José Alípio Goulart (1971, p. 47) ao analisar a aplicação dos castigos pelas esposas dos senhores de engenho:

Conquanto fôssem os senhores uns desalmados, como que sobrevindos de longo e eficiente treino nas diversas câmaras de tortura do inferno criado pelo gênio de Dante, não se davam por menos as mulheres, por vezes mais satânicas que os homens.

Coexistindo com a justiça privada, havia também a justiça oficial que era igualmente aplicada aos escravos, na seara criminal, visto que eles eram seres desprovidos apenas de capacidade cível. Esta última é uma forma de justiça imposta pelo Estado e prevista em lei. Tem-se, portanto, que a justiça oficial no Brasil Colônia só recaia sobre o escravo quando este praticasse algum delito previsto nos textos normativos vigentes.

Acrescente-se, ainda, que em relação aos textos normativos que vigeram no Brasil durante o período colonial, o corpo normativo lusitano que maior aplicação teve em solo brasileiro foi as Ordenações Filipinas - OF, que tem o seu Livro V tratando de matéria criminal, saliente-se que estas Ordenações têm, como principal característica, a previsão de penas cruéis e severas, buscando intimidar o corpo social por meio do terror. De qualquer forma, por mais cruéis que fossem as sanções previstas nas OF, é importante destacar que as penas mais pesadas e infamantes dispostas nas OF eram destinadas aos escravos.

Nesse contexto, embora se verifique a coexistência de duas formas de justiças a que o escravo estava subordinado na época colonial, a justiça privada e a oficial, é importante deixar claro que, quantitativamente, os escravos eram mais punidos pelo julgamento do seu senhor do que por meio da justiça oficial. Ou seja, a quantidade de punições estabelecida aos escravos pelo sistema judicial oficial era menor do que as punições estabelecidas pela justiça privada como resposta à pratica de um delito, sem contar com os castigos que eram aplicados pelos senhores e sinhás a seu bel-prazer. O escravo, neste pensar, tinha maior possibilidade de figurar como réu perante a justiça privada de seu senhor do que pela justiça estatal, fato que justificaria essa predominância do escravo perante a justiça privada de seu senhor em desfavor da justiça 
aplicada pelo Estado se dá, provavelmente, em razão de que, enquanto a primeira era aplicada pelos senhores em suas terras, muitas vezes, a justiça oficial sequer tomava conhecimento da ocorrência dos delitos praticados pelos escravos que, não raramente, já tinha sido punido pela justiça privada. De qualquer forma, não se pode negar a existência de textos normativos vigentes no Brasil no período colonial que tratavam e disciplinavam o comportamento dos escravos.

\section{A LEGISLAÇÃO CRIMINAL VIGENTE NO PERÍODO COLONIAL}

No que se refere à legislação positiva regulamentadora que vigeu no Brasil, pode-se dizer que as primeiras disposições legais da fase colonial foram as Cartas de Doações e os Forais. Destaque-se que a existência do Foral supunha a existência prévia da Carta de Doação, documento este que era responsável por estabelecer a figura do Donatário, bem como os seus direitos e privilégios. Deste modo, percebe-se que a Carta de Doação se tratava de um documento que regulamentava a concessão das capitanias para seus donatários, que passava a ter posse transmissível hereditariamente. Já o Foral consistia em um documento concedido pelo rei que estabelecia, assim como nas Cartas de Doações, os direitos e deveres dos donatários e, além disto, também dispunha acerca dos direitos e deveres dos colonos em relação tanto ao seu respectivo donatário quanto à Coroa portuguesa.

Em Pernambuco, por exemplo, o processo de colonização teve início com a Carta de Doação da Capitania de Pernambuco, de 25 de setembro de 1534, em que o rei D. João III outorga ao donatário Duarte Coelho e a seus descendentes a jurisdição civil e criminal da dita terra, podendo decretar até mesmo a pena de morte para os escravos e peões. Ou seja, a Coroa lusitana concedeu aos donatários plenos poderes, nos limites territoriais de suas capitanias, tanto judiciais quanto policiais, autorizando o emprego do direito baseado em critérios próprios, em uma espécie de carta branca punitiva. Tem-se, portanto, que, com as Cartas de Doações, o monarca português acabava transformando os donatários em senhores das terras e da justiça.

Entretanto, em 1548, com a constatação do fracasso do sistema das capitanias hereditárias, foi estabelecido em terras brasílicas o sistema de Governo-geral, com o objetivo de restabelecer o domínio português sobre toda a extensão da colônia. Destarte, com o advento deste sistema de centralização político-administrativa, houve também a reestruturação do judiciário. Com isso, os direitos dos colonos livres e dos escravos que se codificavam perante a vontade e os atos do donatário, passaram a ser codificados pela Metrópole, passando a viger 
para toda a Colônia a legislação portuguesa contida nas Ordenações do Reino, em especial as Ordenações Filipinas - OF, o que acabou por colaborar, desta forma, para a construção de uma certa uniformidade na aplicação da justiça no Brasil.

Nesse sentido, é importante ressaltar, que os textos normativos produzidos voltados diretamente para o disciplinamento do comportamento dos escravos não constituíram qualquer um dos cinco livros das Ordenações do Reino, muito menos foi criado um código à parte. Desta forma, pode-se afirmar que não houve um Código Negro no Brasil, a exemplo dos que existiram em outras partes da América. Contudo, é pertinente salientar, que, embora as OF não tenham como principal escopo regular os escravos, nelas existiam algumas normas esparsas referentes aos escravos. Nessa perspectiva, pode-se afirmar que o ordenamento jurídico das leis voltada aos escravos no Brasil era aberto, ou seja, não era compilado em um único corpo normativo, mas era formado por várias leis extravagantes que foram criadas para regular o comportamento dos escravos perante a justiça oficial, ou seja, não havia um código e, tendo em vista que, quando as Ordenações se mostravam insuficientes, eram promulgadas leis extravagantes que regulassem o comportamento das res criminalmente.

\subsection{As ordenações portuguesas e as normas extravagantes}

No início do século XV, Portugal sente a necessidade de organizar o seu sistema normativo, tendo em vista que a grande quantidade de normas jurídicas existentes e vigentes, advindas, por exemplo, das Leis Régias, do Direito Romano e do Direito Canônico, causavam contradições em sua aplicação. Assim sendo, por determinação de D. João I, é realizada uma compilação dos direitos positivos para que se possa distribuir uma justiça com maior facilidade para o juiz e maior segurança ao postulante, sendo esta compilação promulgada apenas no reinado de D. Afonso V. Com isto, em 1446, é promulgada a primeira das Ordenações do Reino, a Ordenação Afonsina - OA, que tinha como principal fonte o Direito Romano e o Direito Canônico. Destaque-se que esta Ordenação do Reino, assim como ressalta Thompson (1976, p. 82), representou a primeira codificação de todo o continente europeu após a Idade Média, sendo substituída apenas em 1521, quando D. Manuel promulga as Ordenações Manuelinas - OM, que consistiam na revisão das Ordenações Afonsinas - OA e da recompilação das leis extravagantes que surgiram após a entrada em vigor das OA. As Ordenações promulgadas durante o reino de D. Manuel duraram pouco mais de 80 anos, sendo revogadas em 1603, quando foi promulgada, durante o reinado de Felipe II, a última Ordenação da trilogia, as 
Ordenações Filipinas - OF, que tinham como fonte as Ordenações Manuelinas e as legislações editadas posteriormente à entrada em vigor desta, ou seja, as normas extravagantes.

As Ordenações abrangiam juridicamente não só a sede do império, mas também todas as suas colônias. Entretanto, pode-se afirmar que, no Brasil, das 03 (três) Ordenações do Reino (Afonsinas, Manuelinas e Filipinas), a que mais influenciou o cotidiano da colônia, principalmente na Capitania de Pernambuco, foram as Ordenações Filipinas. Isto porque, embora que no momento da chegada dos primeiros portugueses no Brasil, em 1500, o regime jurídico que regia Portugal era as Ordenações Afonsinas, que vigoraram até 1521, o processo de colonização de fato do Brasil começou apenas em 1530, quando em Portugal já estavam em vigor as Ordenações Manuelinas e mesmo assim esta última não teve aplicação no Brasil enquanto o sistema de organização político-administrativa da colônia era o de Capitanias Hereditárias.

Desta forma, tem-se que, embora as Ordenações Manuelinas estivessem formalmente vigorando no Brasil (CRISTIANI, 2011, p. 433), quando da colonização de fato pelos lusitanos, assim como vigiam em qualquer outra colônia portuguesa, posto que era o Direito que utilizado pela própria Metrópole, este corpo normativo não tinha qualquer aplicação prática em terras brasileiras, sobretudo em razão da determinação da Coroa lusitana, por meio das Cartas de Doação, que estabelecia que quem determinaria o direito a ser utilizado no Brasil era o donatário, que poderia fazer uso desta prerrogativa se baseando em critérios próprio, podendo, portanto, desconsiderar o preceituado nas Ordenações, posto que o mais importante, para a Coroa, assim como evidencia Antônio Carlos Wolkmer (1998, p. 49), seria a proteção de sua Colônia na América e o recebimento dos impostos e demais tributos aduaneiros.

Posteriormente, em 1548, com a restruturação político-administrativa da colônia portuguesa na América, por meio da adoção do sistema de Governo-geral, em que buscou, inclusive, uma centralização jurídica (CRISTIANI, 2011, p. 434), as Ordenações do Reino começaram a ser aplicadas na Colônia. Contudo, na Capitania de Duarte Coelho, em primeiro momento, este processo reestruturante não exerceu qualquer influência, vez que o Donatário Duarte Coelho requereu, ao Rei de Portugal, que sua Capitania não sofresse qualquer tipo de intervenção jurisdicional do Governo-geral, de forma que apenas ele, o donatário, poderia dizer e aplicar o direito por toda a extensão territorial da Capitania pernambucana. Esta situação só foi modificada em 1557, por meio do alvará de 05 de março, quando Duarte Coelho não era mais o Donatário de Pernambuco, que limitou a alçada do capitão-donatário no que se refere a 
peões cristãos e homens livres, estabelecendo-se o poder de apelação em alguns casos. Ressaltese que, até o advento deste alvará, o Donatário tinha, segundo a Carta de Doação, alçada de morte, inclusive, sem direito a qualquer apelação pelo condenado.

Dessa maneira, mesmo que as Ordenações Manuelinas só tenham sido revogadas em 1603, tendo vigorado especificamente na Capitania de Pernambuco por um período de 46 anos, pode-se afirmar que as Ordenações Filipinas, dentre todas as Ordenações do Reino, são o corpo normativo que maior destaque teve no Brasil, tendo em vista que vigoraram durante o resto do período colonial, sendo aplicadas por mais de 200 anos. Destaque-se, ainda, que, em relação às OF, o seu Livro V produziu o primeiro diploma penal que de fato vigorou no Brasil que tratava, ainda que esparsamente, do negro escravo, punindo-os em caso da prática de algum delito ali previsto. O Livro V vigeu, no Brasil, até a entrada em vigor do Código Criminal do Império.

\subsubsection{Aplicação do Livro V das Ordenações Filipinas e suas normas extravagantes}

A lei penal que deveria ser aplicada no país estava contida nos 143 títulos do Livro V das Ordenações Filipinas e nas demais leis extravagantes que vigeram em terras brasílicas. As leis refletiam, antes de qualquer coisa, sob um olhar atual, um Direito Penal dos tempos medievais, fundamentavam-se nos preceitos religiosos, confundindo, não raramente, crime com o pecado e com a ofensa moral. Pretendia-se, por meio destas leis, a contenção dos homens por meio do terror, com a utilização de punições drásticas, com especial predomínio da pena de morte.

Nessa perspectiva, é importante salientar, que o Princípio da Igualdade, sob a perspectiva da isonomia das partes perante o Direito Penal, era ignorado, uma vez que, para o mesmo crime existiam diferentes penalidades. Ou seja, levava-se em consideração tanto a posição social do infrator quanto a classe social da vítima no momento da aplicação da pena, deixando, inclusive, em alguns casos, ao arbítrio do julgador a escolha da pena a ser aplicada, por intermédio da adoção da pena arbitrária.

Evidenciando-se, portanto, a distinção da qualidade da pena em razão da classe social dos agentes envolvidos, ao analisar as Ordenações Filipinas, verifica-se que a condição de escravo era um fator agravante à penalidade aplicada a eles, uma vez que, suas penas eram as mais pesadas e infamantes do que as penas destinadas aos demais membros do corpo social, assim como se pode observar do Título 80, do Livro V, das Ordenações Filipinas: 
TITULO LXXX - Das armas que são defesas e quando se devem perder

$[\ldots]$

Arcabuzes

13 - Defendemos outrossim que pessoa alguma, em todos os nossos reinos e senhorios, não traga, de dia nem de noite, nem tenha em sua casa, arcabuzes de menos comprimento que de quatro palmos em cano; e sendo peão o que o trouxer, seja açoitado e degredado para sempre para as galés.

E, sendo pessoa de maior qualidade, seja degredado para o Brasil para sempre.

E, sendo escravo, morra morte natural.

[...] (LARA, 1999, p.254) (grifo nosso)

Da leitura tanto das Ordenações Filipinas quanto das normas extravagantes que entraram em vigor em terras brasileiras já é possível perceber a distinção existente entre a nobreza (que era considerada como "pessoa de maior qualidade”), o peão e o escravo quando do momento da punição, de maneira objetiva, já que estava expressamente determinada esta distinção no tratamento punitivo. Entretanto, é importante compreender que, embora todo o direito criado pelo governo português tivesse aplicação direta no Brasil, ainda que formalmente, no plano material, nem todas as leis criadas para reger o cotidiano da sociedade da Metrópole eram de fácil aplicação no Brasil, por isso, algumas eram adaptadas devido às especificidades da colônia. Desta forma, tem-se, por exemplo, que, quando nas OF fossem determinadas para pessoa de maior qualidade a pena de degredo para o Brasil e, o criminoso já residisse no Brasil, haveria uma adaptação e o condenado, assim, seria degredado, para outra colônia portuguesa, quando não ocorresse até mesmo a extinção da punibilidade, tendo em vista que no Brasil, muitas vezes os senhores tinham mais poderes do que a própria justiça.

As penas que eram destinadas aos escravos eram, em sua maioria, corporais, como, por exemplo, o açoitamento público, sendo a mais drástica a pena capital, que era, nas Ordenações do Reino, a pena por excelência. Demais disto, é importante frisar que, diante das formas como a pena de morte poderia ser aplicada, tem-se que, geralmente, era executada por intermédio do enforcamento ou por degolação. Entretanto, aos escravos, a forma pela qual a vida era retirada era mediante o enforcamento, sobretudo por se tratar de um meio mais infamante e que não era, portanto, aplicada às pessoas de “maior qualidade”, que, quando punidas com a pena capital, tinham sua pena aplicada por meio do degolamento. 
Tem-se, portanto, que, além da diferença das penas abstratamente cominadas em razão da classe social do agente, mesmo quando o escravo e os demais entes da sociedade cometiam delitos cuja a pena legislativamente prevista fosse a pena de morte, a reprimenda penal destinada ao escravo seria ainda mais pesada, considerando que, além de morrer por enforcamento, enquanto os nobres morreriam por meio da degolação, antes da morte o escravo seria atenazado (castigo que aperta a carne) e teria suas mãos decepadas, como é estabelecido, por exemplo, do Título XLI, do Livro V, das Ordenações Filipinas - Dos escravos ou filhos que arrancar arma contra seu senhor ou pai:

TITULO XLI - Dos escravos ou filhos que arrancar arma contra seu senhor ou pai O escravo, ora seja cristão ora o não seja, que matar seu senhor ou filho de seu senhor, seja atenazado e lhe sejam decepadas as mãos, e morra morte natural na forca para sempre; e se ferir o seu senhor sem o matar, morra morte natural. $E$ se arrancar alguma arma contra seu senhor posto que o não fira seja açoitado publicamente com baraço e pregão pela Vila, e seja lhe decepada uma mão. 1 - E o filho ou filha que ferir seu pai ou mãe com intenção de os matar, posto que não morram das tais feridas, morra morte natural. (LARA, 1999, p.158) (grifo nosso).

Em alguns momentos entra em discussão, nas próprias Ordenações Filipinas, a questão se o escravo é homem ou res, na forma de diferenciação da pena, tendo em vista, por exemplo, da análise do Título LX, do Livro V, das OF, em que, quando se tratasse de furto cujo o objeto do furto valesse menos de quatrocentos réis, o legislador, por intermédio das OF, determinava que qualquer pessoa seria açoitada publicamente, podendo-lhe ser aplicada outra pena corporal menos atroz. Entretanto, para o escravo, não importando o valor, seria açoitado publicamente, não havendo uma pena alternativa como havia com “qualquer pessoa”.

TITULO LX - Dos furtos e dos que trazem artifícios para abrir a porta [...]

2 - E qualquer pessoa que furtar valia de quatrocentos reis e dai para cima, não sendo o furto de qualidade por que deva morrer, seja publicamente açoitado com baraço e pregão; e sendo de valia de quatrocentos réis para baixo será acoitado publicamente com baraço e pregão ou lhe será dada outra menor pena corporal que aos Julgadores bem parecer, havendo respeito à quantidade e qualidade do furto e do ladrão. 
Porém, se for escravo, quer seja Christão quer infiel, e furtar valia de quatrocentos reis para baixo, será açoitado publicamente com baraço e pregão.

[...] (LARA, 1999, p.194) (grifo nosso).

Já em relação às normas penais extravagantes, elas eram incorporadas nas compilações das novas Ordenações. Ou seja, todas as 3 (três) Ordenações que vigeram em Portugal tinham como principal escopo a compilação das diversas leis que surgiam. Com isso, todas as normas extravagantes anteriores a 1602, encontra-se disposta nas próprias Ordenações Filipinas. Entretanto, à medida em que as Ordenações se mostravam insuficientes para regular determinadas situações, eram promulgadas novas leis extravagantes. Desta maneira, em razão das especificidades da colônia, muitas vezes era necessária a elaboração de novas leis que atendessem aos interesses do corpo social colonial, leis estas que eram destinadas especificamente para a realidade da colônia portuguesa na América. Desta forma, algumas dessas leis extravagantes emitidas pelo governo lusitano com o objetivo de regular o cotidiano da Colônia também tratava dos escravos africanos, como, por exemplo, do Alvará de 07 de março de 1741, em que determina que todos os negros fugidos que fossem encontrados em quilombos fossem marcados, com ferro em brasa, com a letra "F" na testa. E, em caso de reincidência, teria a orelha cortada.

\subsection{O Direito Penal no período holandês}

De 1630 a 1654, a Colônia de Pernambuco ficou sob administração holandesa, durante este período as Ordenações dos Reinos foram substituídas pela legislação vigente na Holanda, entrando em um hiato que perdurou 24 anos. Entretanto, mesmo que existam poucos registros sobre a aplicação da lei penal na então denominada “Nova Holanda”, pode-se afirmar que no Código holandês aplicado no Brasil havia muitas leis penais igualmente caracterizadas pelo rigor, possuindo a pena de morte, não tão diferentemente como nas Ordenações do Reino, como a pena por excelência, sobretudo porque o conde João Maurício de Nassau-Siegen, ao chegar no novo domínio holandês, em 23 de janeiro de 1637, revogou as leis penais que cominassem as penas mais leves. A partir da chegada de Maurício de Nassau é que há uma maior preocupação em relação ao direito a ser utilizado na Nova Holanda (PINHO, 1954, p. 398).

Em razão de que a pena de morte fosse a pena mais largamente utilizada no novo domínio holandês na América, com a revogação dos crimes cujas as penas fossem mais brandas, 
ao contrário do que era objetivamente previsto nas Ordenações Portuguesas, não havia uma segregação social tão evidente quando da aplicação da reprimenda penal. Ou seja, em princípio, pode-se até afirmar que, objetivamente, era respeitado o princípio da igualdade das partes.

Embora que da análise dos poucos documentos normativos colhidos, possa-se afirmar que não há expressamente uma diferenciação pré-estabelecida no momento da dosimetria da pena, podendo-se dizer, que havia, aparentemente, uma igualdade abstrata, realizada antes da aplicação da pena de fato pelo juiz, é importante evidenciar que: (i) haviam normas penais especialmente destinadas à determinados membros da sociedade; (ii) bem como a escravidão era uma forma de pena aplicada aos condenados perante o direito vigente na época, sendo possível, desta forma, a escravização do homem como forma de pena, assim como demonstra Ruy Rebello Pinho em sua análise sobre o direito penal no Brasil holandês:

\footnotetext{
De certo modo, a escravidão também foi uma pena aplicada no tempos dos batavos, pelo menos em relação aos índios. Houve um momento "em que se permitiu a escravização dos índios, logo proibida. Tratava-se de índios, que faziam guerra aos que se haviam aliado aos holandeses: como castigo foram escravizados" (sic) (1954, p. 439) (grifo do autor).
}

De qualquer forma, muito embora não haja evidencias concretas da diferenciação na punição dos agentes em conformidade com a sua classe social, pode-se afirmar que a administração holandesa no Brasil se preocupava em punir com maior severidade os portugueses e nativos que se levantavam sobre o domínio. Desta forma, o que se observa é que, como a sanção mais aplicada era a pena capital, não havia a necessidade de uma diferenciação prevista legislativamente, como havia nas Ordernações. Ademais, os holandeses demostraram até mesmo um certo interesse sob os escravos africanos, protegendo-os, sobretudo em razão da previsão legal contida no ordenamento jurídico holandês, assim como afirma José Antônio Gonsalves de Mello (1947, p. 159 e 221), que determinava que toda e qualquer mutilação de membros ou até mesmo realização de marcas de ferro a serem feitas pelos senhores sob os corpos de seus escravos deveriam ter uma autorização prévia a ser concedida pelo próprio governo.

\subsection{Direito Penal nos quilombos como um direito rústico}


Quilombo era a comunidade em que os escravos que fugiam da exploração e dos maus tratos dos senhores de engenho se reuniam para levarem uma vida livre. A primeira definição formal que se tem acerca de quilombo, de acordo com Alfredo Wagner Berno de Almeida (2002, p. 47), deu-se apenas em 1740, por intermédio do Conselho Ultramarino da Coroa lusitana. De acordo com o mencionado Conselho, quilombo era "toda habitação de negros fugidos, que passem de cinco, em parte despovoada, ainda que não tenham ranchos levantados e nem se achem pilões nele”.

A proteção do corpo social quilombola, era um dos elementos mais importantes desta comunidade e, sobre esta proteção, essa preocupação com o corpo social, é que se desenvolveu os principais quilombos. Palmares, por exemplo, assim como relata Clóvis Moura (1987, pp. 53-54), foi um dos quilombos com grande preocupação no desenvolvimento de uma organização militar que fosse capaz de oferecer segurança a todos os quilombolas.

Ressalte-se que essa preocupação com a proteção do corpo social não levava, obrigatoriamente, a uma indistinção dos membros da sociedade, isto porque, nos quilombos também existiam a distinção por classe social, fazendo com que, inclusive, existissem escravos trabalhando forçadamente dentro dos próprios quilombos (NARLOCH, 2009, p. 45). No quilombo de Palmares, por exemplo, os escravos que lá chegavam por sua própria vontade eram considerados homens livres. Entretanto, caso eles entrassem no quilombo de forma forçada, continuava sendo considerado escravo do quilombo.

Este fato de existir uma organização social tão estratificada dentro das comunidades quilombolas é em razão, sobretudo porque:

\begin{abstract}
A realeza fazia parte da organização social de muitos povos africanos. Era assim que concebiam sua organização. Tal fato pode ser constatado na organização dos quilombos no Brasil. Quando fugiam, os escravos se organizavam em comunidades sob o governo de um rei e de uma rainha. Além da figura do rei-guerreiro, também era comum a presença do rei-sacerdote e divino, responsável por presidir as colheitas e mediar a relação da comunidade dos espíritos ancestrais. (FIGUEIREDO, 2013, p. 170-171).
\end{abstract}

Nos quilombos o direito não era definido por um código, os crimes eram punidos por meio de um direito consuetudinário. Os costumes do quilombo é que definiriam as ações que se configurariam como delitos ou não. Logo, verifica-se a coexistência, no Brasil colonial, de 
um direito rústico, ou seja, não oficial, porém eficaz perante a massa social. Assim, constata-se uma cultura jurídica popular formada por um grupo social culturalmente marginalizado, contudo, estatisticamente dominante, que acabava por afastar a aplicação da lei oficial em detrimentos de suas próprias.

Destaque-se que a existência de um direito rústico, no domínio português na América em muito se aproxima ao pluralismo jurídico existente na Idade Média apontado por António Manuel Hespanha (2012, p. 148), marcada pela coexistência de um “direito comum” e de “direitos próprios”. Neste pensar, o direito aplicado dentro dos quilombos, ainda que se constituísse de um direito consuetudinário, comportar-se-ia como um direito próprio, mas quase que excluído do conceito de direito, sobretudo em razão de sua natureza. Assim como as formas de direitos que eram assim consideradas no período medieval, o direito dos quilombos também pode ser considerado um direito rústico que compôs o pluralismo jurídico colonial, como uma forma de percepção do poder periférico.

Nesse sentido, é relevante esclarecer que nos quilombos os crimes que eram punidos com maior severidade eram os delitos de adultério, o homicídio e o roubo individual. Por se tratar de uma propriedade coletiva, embora estratificada, vale ressaltar, esses delitos eram considerados uma lesão a todos os membros da comunidade, como uma forma de perda da "paz social”. Além do crime de traição contra o quilombo, que era punido com a pena capital.

No Quilombo de Palmares, por exemplo, toda pessoa que se incorporasse ao corpo social era proibida de sair. Ou seja, toda pessoa que se tornasse quilombola não teria mais a liberdade de querer deixar de ser, sobretudo porque, se assim preferissem, seria condenada à pena capital, visto que os demais membros dos quilombos, “[...] quando alguns negros fugiam, mandava-lhes crioulos no encalço e uma vez pegados, eram mortos, de sorte que entre eles reinava o temor” (GOMES, 2015).

\section{MAPEAMENTO E ANÁLISE DOS PROCESSOS JUDICIAIS PENAIS}

Para melhor entender a história jurídica de um povo é de suma importância, além da análise de sua legislação, realizar um estudo acerca do processo de aplicação dessas leis. Nesse sentido, para melhor compreensão da aplicação do direito penal no Brasil Colônia, em especial na Capitania de Pernambuco, fez-se necessário a realização de um mapeamento, por intermédio de consultas à organismos nacionais e internacionais, em museus e arquivos públicos para que assim se tornasse possível a arrecadação de documentação processual-criminal que 
possibilitasse a construção de um conhecimento mais aprofundado acerca da aplicação do direito além do contexto abstrato.

Desta maneira, por meio do mapeamento, foi possível encontrar documentos, principalmente em Pernambuco, no plano nacional, e em Portugal e Holanda, no plano internacional, que poderiam, de alguma forma, corroborar com a formação de um conhecimento mais apurado acerca da cultura punitiva na Capitania de Pernambuco durante o período colonial.

\subsection{Processos em Pernambuco}

Em pesquisas feitas no Memorial da Justiça de Pernambuco, com a finalidade de obter documentação proveniente do período colonial, nenhum processo do mencionado período colonial referente a Recife foi encontrado. Entretanto, foram encontradas sete caixas com 96 processos, referentes ao período da colônia de comarcas do interior de Pernambuco. Existem, portanto, no Memorial da Justiça de Pernambuco, o total de 46 processos criminais da comarca de Flores, entre os anos de 1778 e 1817; 1 processo da comarca de Afogados da Ingazeira, de 1810, referente ao crime de homicídio; 31 processos da comarca de Serra Talhada entre 1769 e 1820, em que se destaca um processo sobre apreensão de escravo; 17 procedimentos criminais da comarca de Garanhuns entre os anos de 1748 e 1814, em que se verifica a existência de um processo sobre furto de escravo; e 1(um) processo criminal da comarca de Paudalho de 1807.

Muito embora, tenham sido localizados estes processos, a realização de uma leitura deles não foi possível, sobretudo em razão do elevado grau de deterioração destes documentos, posto que se encontravam muito danificados. A análise processual corroboraria, após a identificação dos procedimentos que tinham como réus os escravos, na realização de um estudo mais detido acerca das penas concretamente a eles aplicadas. Além do mais, a análise das partes não deterioradas demandaria uma leitura paleográfica, pois esses processos não estão digitalizados e nem atualizados para o português atual.

\subsection{Processos do período holandês}

Não se pode esquecer da ocupação holandesa por um período de 24 anos no Brasil Colônia, mais especificamente na Capitania de Pernambuco. Desta maneira, em contatos estabelecidos com o Arquivo Nacional da Holanda, com o objetivo de obter maiores informações sobre a aplicabilidade do regime jurídico-penal na Nova Holanda, foi 
disponibilizado acesso a alguns documentos digitalizados, disponíveis no site do órgão. Contudo não foi possível realizar a leitura destes documentos, com fito de detectar quais eram destinados aos escravos, pois, para efetuar a leitura desses registros, necessitária de um tradutor de holandês arcaico e um paleógrafo, tendo em vista o tipo de caligrafia utilizado.

\subsection{Processos do Tribunal do Santo Ofício}

A sociedade portuguesa tinha uma forte conexão com a religião, sobretudo a Católica, exemplo disto é que as Ordenações do Reino tinham grande influência do Direito Canônico. Desta maneira, é importante destacar que, no Brasil, também houve a presença da Justiça Eclesiástica, por intermédio das Visitações do Santo Ofício, que julgavam no Tribunal Inquisitorial, localizado em Portugal, os acusados por condutas que atentassem a fé religiosa, os costumes e a moral.

Nesta perspectiva, em pesquisas realizadas no Arquivo Nacional da Torre do Tombo, foram localizados processos do Tribunal do Santo Ofício, uma instituição eclesiástica de caráter judicial, que tinha como propósito investigar, apurar, julgar e condenar os culpados por comportamentos considerados heréticos. Destes documentos processuais, foram encontrados 06 (seis) processos em que escravos da Capitania de Pernambuco figuravam como réus. Entretanto, dos 06 (seis), apenas 05 (cinco) havia sentença.

Dos procedimentos sentenciados, haviam três processos que versavam sobre bigamia. Ao analisar os autos, verificou-se que, em todos, as penas de abjuração de leve e de penitências espirituais se repetiram, ainda que outras penalidades fossem aplicadas em cumulação. Além desses, haviam dois outros processos em que o crime cometido foi o de sodomia. Entretanto, as penas foram distintas, para um, a pena aplicada foi de açoite público e degredo para as galés, por dez anos. Entretanto, o outro, foi asperamente repreendido na Mesa e depois posto em liberdade.

\section{CONSIDERAÇÕES FINAIS}

Para o estudo das normas vigentes aos escravos na Capitania de Pernambuco no período colonial é necessário todo um desenvolvimento histórico, que se inicia quando, com receio de perder as terras brasileiras, Portugal envia uma expedição colonizadora. A partir de 
então, iniciou-se o Período Colonial no Brasil. Durante o processo de colonização, tomou força, sobretudo na Capitania de Pernambuco, o cultivo da cana-de-açúcar. No entanto, como os colonos necessitavam de mão-de-obra, a escravidão de negros oriundos da África apareceu como a melhor solução.

Os negros, agora escravizados, quando aportavam na Colônia, eram tratados como res, sendo reduzidos a instrumentos de seus senhores, além de serem renegados pela própria Igreja Católica, que argumentava que a escravidão era algo destinada ao negro, em virtude, sobretudo, de suas práticas religiosas. Porém, como afirma Jacob Gorender (1985, p. 51), "o primeiro ato humano de um escravo é o crime", visto que, enquanto os negros eram considerados incapazes de adquirir e possuir direitos no âmbito cível, eram plenamente responsáveis no plano criminal.

A partir da coexistência de 02 (duas) justiças no Brasil, a justiça privada, exercida pelos senhores de engenhos, e a justiça oficial, legitimada pela ação do Estado, verificou-se que os castigos, serviam para otimizar a produção econômica, diminuir a força política escravista, além de servir como meio repressivo e preventivo ao crime. Porém, a execução desses castigos, em especial no exercício da justiça exercida pelos seus senhores, muitas vezes, esbarrava na questão da moderação, causando punições muito excessivas, deixando os escravos, não raramente, com deformidades físicas.

Embora na Metrópole, durante o processo de colonização, vigesse as Ordenações do Reino (Ordenações Afonsinas, Manuelinas e Filipinas), a legislação criminal, que se baseava no Livro V das Ordenações Filipinas, texto que maior aplicação teve em terras brasílicas, só entrou em vigor na Capitania de Pernambuco em 1557, por meio do Alvará datado de 05 de março daquele mesmo ano. Ou seja, antes disso, em Pernambuco, vigoraram as leis que se codificavam perante a vontade e atos do Donatário. A partir de 1557, então, é que a legislação criminal portuguesa penetra de fato na malha do corpo social brasileiro, salvo um período de 24 anos em que a aplicabilidade das Ordenações foi suspensa na Capitania de Pernambuco em razão da invasão holandesa, em que a pena aplicada, durante o período da então Nova Holanda, não se diferenciava muito daquelas cominadas nas Ordenações portuguesas, sobretudo porque a pena por excelência era, em ambos códigos, a pena de morte

Demais disto, a partir da análise da principal legislação lusitana aplicada em solo brasileiro, percebe-se que a condição de escravo era um fator agravante à penalidade aplicada. Em razão disto, para fugir da exploração e dos maus tratos dos seus senhores de engenho, muitos escravos se reuniam para levarem uma vida livre nos quilombos. Comunidade formada 
sobretudo por negros escravos fugitivos, onde a norma estabelecida consistia em um direito consuetudinário e, em uma perspectiva sobre o pluralismo jurídico, comportava-se como um direito rústico, que não era oficial, porém eficaz perante o corpo social, em que os crimes que eram punidos com maior severidade eram aqueles considerados lesivos a todos da comunidade.

Após análise das Ordenações Filipinas, pode-se asseverar que existia uma grande distinção entre as penas aplicadas aos escravos em relação aos demais entes da sociedade. Entretanto, após a realização de um mapeamento dos processos penais que tramitaram no período colonial em Pernambuco, percebeu-se acerca da impossibilidade da realização de uma análise mais apurada acerca desta documentação coletada, sobretudo em razão do elevado grau de danificação. Nada obstante, esta coleta colaborou a perceber que os escravos também foram submetidos, além da justiça privada e oficial, à justiça eclesiástica, por meio das Visitações do Santo Ofício.

\section{REFERÊNCIAS}

ALMEIDA, Alfredo Wagner Berno de. Os quilombos e as novas etnias. In: O‘DWYER, Eliane Cantarino (org.). Quilombos: identidade étnica e territorialidade. Rio de Janeiro: Editora FGV, 2002.

CRISTIANI, Cláudio Valentim. O direito penal no Brasil colonial. In: WOLKMER, Antônio Carlos (Org.). Fundamentos de história do direito. Belo Horizonte: Del Rey, 2011.

DORIA, Pedro. 1565 - Enquanto o Brasil nascia: a aventura de portugueses, franceses, índios e negros na fundação do país. Rio de Janeiro: Nova Fronteira, 2012

FIGUEIREDO, Luciano (Org.). História do Brasil para ocupados: os mais importantes historiadores apresentam de um jeito original os episódios decisivos e os personagens fascinantes que fizeram o nosso país. Rio de Janeiro: Casa da Palavra, 2013.

GOMES, Flávio dos Santos. Mocambos e quilombos: uma história do campesinato negro no Brasil. São Paulo: Claro Enigma, 2015.

GORENDER, Jacob. O Escravismo Colonial. 4 ed. São Paulo: Editora Ática, 1985. 
GOUlART, José Alípio. Da Palmatória ao Patíbulo: castigos de escravos no Brasil. Rio de Janeiro, Editora Conquista, 1971.

HESPANHA, António Manuel. Cultura jurídica europeia: síntese de um milénio. Coimbra: Almedina, 2012.

LARA, Silvia Hunold (Org.). Ordenações Filipinas: Livro V. São Paulo: Companhia das Letras, 1999.

MALHEIRO, Perdigão. A Escravidão no Brasil: ensaios histórico-jurídico-social. 3 ed. Petrópolis, Vozes; Brasília, INL, 1976.

MELLO, José Antônio Gonsalves de. Tempo dos flamengos: influência da ocupação holandesa na vida e na cultura do norte do Brasil. Rio de Janeiro: José Olympio, 1947.

MOURA, Clóvis. História do Negro Brasileiro. São Paulo: Editora Ática S.A.,1989.

MOURA, Clóvis. Quilombos: resistência ao escravismo. São Paulo: Editora Ática S.A.,1987.

MOURA, Clóvis. Sociologia do Negro Brasileiro. São Paulo: Editora Ática S.A.,1988.

NARLOCH, Leandro. Guia politicamente incorreto da história do Brasil. São Paulo: Leya, 2009.

NETO, Vicente Amêndola Neto. História e evolução do Direito Penal no Brasil. Campinas: Julex Livros Ltda., 1997.

PIERANGELI, José Henrique. Códigos Penais do Brasil: Evolução histórica. $2^{\mathrm{a}}$ ed. São Paulo: Editora Revista dos Tribunais, 2004.

PINHO, Ruy Rebello. A organização da justiça, o processo penal e o direito penal no Brasil holandês. Revista da Faculdade de Direito da Universidade de São Paulo, São Paulo. 1954. Disponível em <http://www.revistas.usp.br/rfdusp/article/view/66217>. Acesso em 13 de março de 2018.

RAMOS, Arthur. Introdução à antropologia brasileira: As culturas europeias e europeizadas. $3^{\mathrm{a}}$ ed. Rio de Janeiro: Livraria-Editora da C.E.B., 1975. $4^{\circ}$ volume. 
THOMPSON, Augusto F. G. Escorço histórico do direito criminal luso-brasileiro. São Paulo: Editora Revista dos Tribunais, 1976.

VASCONCELOS, Karina Nogueira; OLIVEIRA, Rodrigo Teles. Penalidade e colônia: Da liberdade punitiva às Ordenações Filipinas numa análise da punibilidade dos homens livres na Capitania de Pernambuco. Revista Brasileira de História do Direito, v. 2, p. 261-283, 2016.

WEHLING, Arno; WEHLING, Maria José C. M. Formação do Brasil Colonial. 2ed. Rio de Janeiro: Nova Fronteira, 1999.

WOLKMER, Antônio Carlos (Org.). Humanismo e cultura Jurídica no Brasil. Florianópolis: Fundação Boiteux, 2003.

WOLKMER, Antônio Carlos. História do direito no Brasil. Rio de Janeiro: Forense, 1998. 